Z. dt. Ges. Geowiss., 162/2, p. 117-126, 6 figs.

Stuttgart, June 2011

Article

\title{
Interaction between eustacy and block-faulting in the Carboniferous of the Visé - Maastricht area (Belgium, The Netherlands)
}

\author{
Edouard Poty \& Sandrine Delculée*
}

Poty, E. \& Delculée, S. (2011): Interaction between eustacy and block-faulting in the Carboniferous of the Visé - Maastricht area (Belgium, The Netherlands). [Wechselwirkungen zwischen Eustasie und „Block-Faulting“ im Karbon der Region Visé - Maastricht (Belgien, Niederlande)] - Z. dt. Ges. Geowiss., 162: 117-126, Stuttgart.

\begin{abstract}
The Visé-Maastricht sedimentation area (VSA) is situated at the eastern end of the Brabant Massif and suffered block-faulting tectonics during Lower Carboniferous time. The south edge of the VSA, the area corresponding now to the vicinity of Visé, comprised three main tectonic blocks: the Hermalle-sous-Argenteau, Souvré and Bombaye blocks. They were bounded to south by the Booze-Val-Dieu block. To the north, in the vicinity of Maastricht, blocks are not well differentiated and are referred to as the Maastricht block system. From the end of the Tournaisian, the latter evolved into a rapidly subsiding graben, recording mainly debris flows and limestone turbidites, whereas the southern blocks remained relatively high. Through much of Lower Carboniferous time, they were emergent, but during high eustatic sea levels, they were flooded and covered by limestone deposits. The differences in the nature and the age of the deposits between blocks result from the interaction between block-faulting and eustacy.

In the VSA, the Upper Devonian and Lower Tournaisian (Hastarian) deposits are similar to those known in the north part of the Namur-Dinant Basin. But from the late Tournaisian (Ivorian), the uplift of the Booze-Val-Dieu block prevented all connections with the Namur-Dinant Basin and the VSA became linked with the Campine Basin.

The Souvré block subsided from the latest Givetian to the late Frasnian and recorded a thick middle Frasnian limestone series, but was later emergent, so much that karstic cavities developed. The Souvré block was submerged for a short time at the top of the Tournaisian, during the very high highstand (HST) corresponding to eustatic sequence 4, and the caves filled up with sediments.

The Hermalle-sous-Argenteau and the Bombaye blocks, situated respectively west and east of the Souvré block, evolved in the same way during the late Devonian. They subsided slightly from the earliest Tournaisian to the late Viséan (Warnantian), but usually remained emergent and recorded deposits only during times of high eustatic levels corresponding to the early Tournaisian (for the Bombaye block), the end of the Tournaisian (HST of sequence 4), the end of the early Viséan (HST of sequence 6), then the late Viséan (HST of sequences 9 and 10). In its southern part, the Hermalle-sous-Argenteau block recorded also lowermost Viséan limestones correlated with the highstand of the eustatic sequence 5, probably as a result of the tilting of the block to the south at this time.
\end{abstract}

Kurzfassung: Der Sedimentationsraum Visé-Maastricht (VSA) befindet sich am östlichen Ende des Brabanter Massivs und ist im Unterkarbon durch „,block-faulting“-Tektonik geprägt. Das südliche Ende des VSA, heute die Umgebung von Visé umfassend, kann in drei tektonische Blöcke untergliedert werden: Hermalle-sous-Argenteau-Block, Souvré-Block und Bombaye-Block. Diese werden nach Süden vom Booze-Val-Dieu-Block begrenzt. Im Norden, in der Umgebung von Maastricht, können einzelne Blöcke nicht differenziert werden und sind daher zum Maastricht-Block-System zusammengefasst. Ab dem Ende des Tournaisiums entwickelt sich das Maastricht-Block-System in einen hoch subsidenten Graben, in dem hauptsächlich Schuttströme und Calciturbidite abgelagert werden, während die südlichen Blöcke zeitgleich relativ hoch gelegen verbleiben. Für die meiste Zeit des Unterkarbons sind diese Gebiete aufgetaucht, aber sie wurden während hoher Meeresspiegelstände überflutet und Karbonate lagerten sich ab. Die Unterschiede in der Art und dem Alter der Ablagerungen zwischen den einzelnen Blöcken resultieren aus dem Zusammenspiel von ,block-faulting“ und eustatischen Meeresspiegelschwankungen.

Im VSA sind die Ablagerungen des Oberdevons und unteren Tournaisiums (Hastarium) vergleichbar mit den altersgleichen Ablagerungen des nördlichen Namur-Dinant-Beckens. Aber ab dem oberen Tournaisium (Ivorium) verhindert das Aufsteigen des Booze-Val-Dieu-Blocks die Verbindung von VSA und dem Namur-Dinant-Becken und der VSA wurde an das Campine-Becken angeschlossen.

Der Souvré-Block war vom höchsten Givetium bis zum oberen Frasnium subsident und mächtige mittelfrasnische Kalksteine wurden abgelagert. Diese wurden später herausgehoben und ein Karstsystem entwickelte sich. Der Souvré-Block wurde im höchsten Tournaisium wieder kurzeitig überflutet und in den Karstsystemen wurde unter marinen Bedingungen

\footnotetext{
*Address of the authors:

Prof. Dr. Edouard Poty (E.poty@ulg.ac.be), Dr. Sandrine Delculée, Paléontologie animale et humaine, Département de Géologie, Université de Liège, Bâtiment B18, allée du 6 Août, B-4000 Liège, Belgium.
} 
Sediment abgelagert. Dieser Zeitpunkt kann mit dem hohen „Highstand“ (HST) der eustatischen Sequenz 4 gleichgesetzt werden.

Die Hermalle-sous-Argenteau und Bombaye-Blöcke, westlich und östlich des Souvré-Blocks, zeigen die gleiche oberdevonische Entwicklung. Sie waren vom frühesten Tournaisium bis späten Viséum (Warnantium) leicht subsident, blieben aber meist aufgetaucht und wurden nur bei hohem eustatischem Meeresspiegel überflutet, so im frühen Tournaisian (für den Bombaye-Block), am Ende des Tournaisiums (HST der Sequenz 4), am Ende des Unterviséums (HST der Sequenz 6) und im späten Viséum (HST der Sequenzen 9 und 10). Am südlichen Ende des Hermalle-sous-Argenteau-Blocks zeigen Kalksteine des frühesten Viséums, korreliert mit dem HST der eustatischen Sequenz 5, möglicherweise eine Kippung des Blocks in südlicher Richtung zu dieser Zeit an.

Keywords: sequence stratigraphy, Lower Carboniferous, Belgium, block-faulting, Visé - Maastricht area

Schlüsselwörter: Sequenzstratigrafie, Unterkarbon, Belgien, „Block-Faulting“, Region Visé - Maastricht

\section{Introduction}

The Visé-Maastricht area is a small, but complex palaeogeographic unit situated at the east end of the Brabant Massif. The recognition of blocks having different tectonic and sedimentary histories has led to the interpretation of the evolution of the area as resulting from the interplay between block-faulting tectonics and sedimentation (Poty 1991). However, that model implied numerous and rapid up and down movements of the blocks that appeared complicated and not always plausible. The application of the Lower Carboniferous sequence stratigraphy rooted in the Belgian Dinantian, then extended to other European basins (Hance et al. 2001,2002 ), and finally to a global model of eustatic variations (Poty \& Hance 2008), leading to a better understanding of the evolution of the southern part of the area.

\section{Geological setting (Fig. 1)}

During the latest Givetian and earliest Frasnian, the Brabant Massif, composed of folded lower Palaeozoic rocks, was affected by a extensional tectonics which gave rise to two halfgrabens, the Campine sedimentation area ("Campine Basin") in the north and the Namur sedimentation area ("Namur Basin") in the south (Poty 1997). The Campine sedimentation area (KSA) was paleogeographically a part of a larger basin extending to the north (The Netherlands) and to the northeast (British Midlands), whereas the Namur sedimentation area (NSA) was paleogeographically a part of the Namur-Dinant Basin. They remained separated by the axial part of the Brabant Massif.

The Visé-Maastricht sedimentation area (VSA) is situated at the east end of the axial part of the Brabant Massif

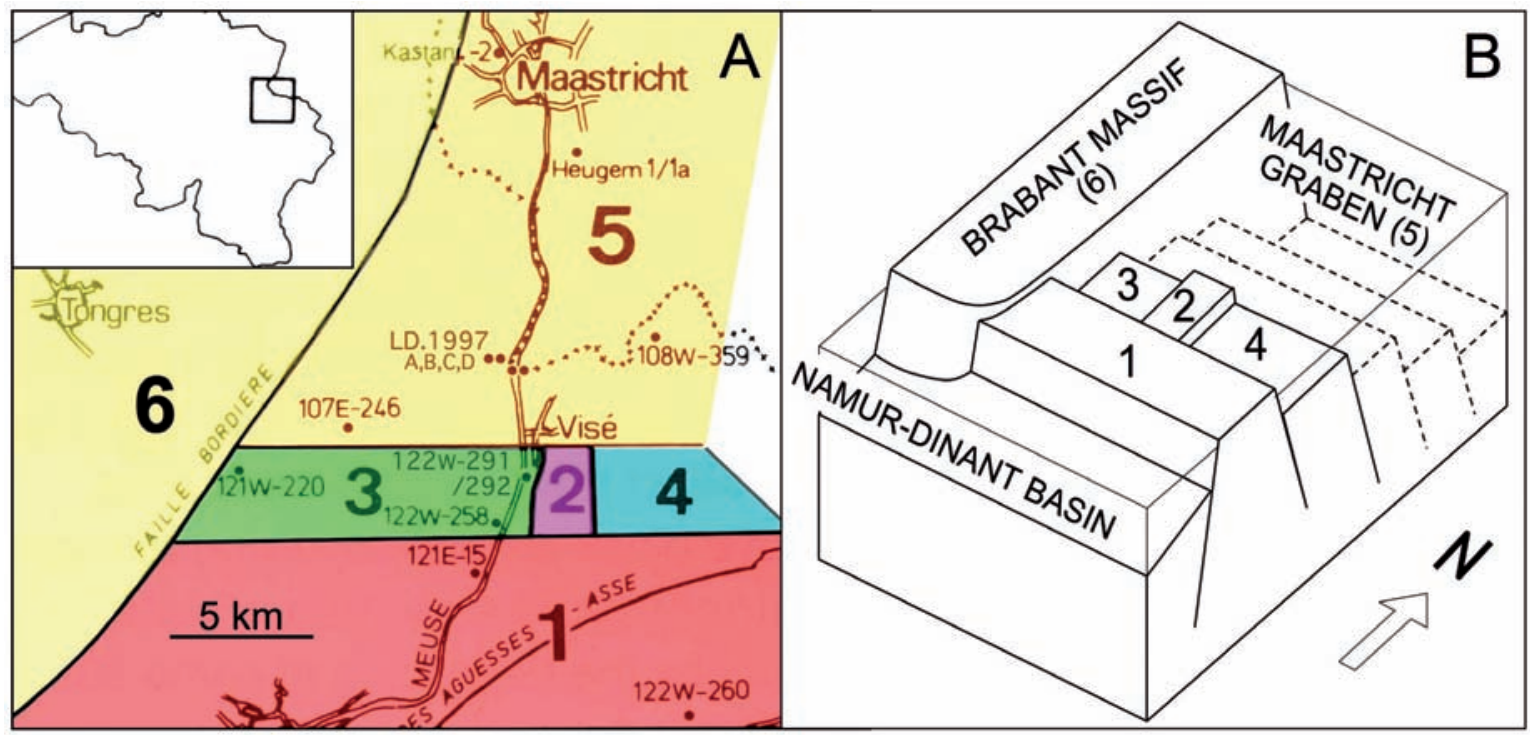

Fig. 1: Location map (A) and relative position of the tectonic units (B) on the eastern end of the Brabant Massif during the Upper Devonian-Carboniferous. Blocks 1-4 correspond to the southern border of the Visé-Maastricht sedimentation area (VSA). Blocks situated northwards (Maastricht block system) were highly subsident and formed the Maastricht Graben. They are not differentiated and are suggested on the figure by dashed lines. 1 = Booze-Val-Dieu block; 2 = Souvré block; 3 = Hermalle-sous-Argenteau block; $4=$ Bombaye block; 5 = Maastricht block system.

Heugem 1/1a, Heugem 1 and 1a boreholes; Kastan-2, Kastanjelaan-2 borehole; LD.1997 A,B,C,D = Lixhe Distrigaz A, B, C and D boreholes; 107E-246 = Houtain-Saint-Siméon borehole; 108W-359 = Gravensvoeren borehole; $121 \mathrm{~W}-220$ = Villers-Saint-Siméon borehole; 121E-15 = Chertal borehole; 122W-258 = Hermalle-sous Argenteau borehole; $122 \mathrm{~W}-260=$ Boland borehole; 122W-291/292 = Visé boreholes. 
and corresponds probably to a small pull-apart basin resulting from a strike slip fault related to the north (KSA) and south (NSA) half-graben structures. It suffered block faulting during the Devono-Carboniferous (Poty 1991). The VSA was connected with the NSA from its inception at the Givetian/Frasnian transition, at least until the end of the Hastarian (early Tournaisian). Thereafter, it was separated from the NSA by the Booze-Val-Dieu ridge (Poty 1997) and was open to the KSA, and its north part evolved to a graben (Maastricht Graben), in which deep water carbonates were deposited.

The Upper Devonian and Dinantian of the VSA crop out only in the vicinity of Visé, which corresponds to its south edge and comprises slowly subsiding to rising blocks. Their stratigraphical succession contains numerous stratigraphic gaps. The stratigraphical succession becomes more complete northward in the Maastricht Graben. The upper slope of the Maastricht Graben is known from outcrops, but the graben itself is only known from boreholes north of Visé and in the vicinity of Maastricht.

Three main tectonic blocks were recognised at the south edge of the VSA (Poty 1991). They are from west to east: the Hermalle-sous-Argenteau (Fig. 1: block 3), the Souvré (Fig. 1; block 2) and the Bombaye block (Fig. 1: block 4). They are bounded to the south by the Booze-Val-Dieu block (Fig. 1: block 1), which formed a high separating the VSA from the NSA, from the late Tournaisian until the late Viséan. To the north, there are several blocks which subsided more rapidly during the Dinantian (Fig. 1: 5). They are not differentiated and were grouped in the Maastricht block system by Poty (1991). The northward extension of the VSA is unknown, but it was open to the Campine Basin.

\section{Stratigraphic setting (Fig. 2)}

For the Devonian, correlations have been based on lithostratigraphy, palynomorphs (spores and acritarchs), corals, conodonts and foraminifers, depending of the lithology and the age of the rocks. The biostratigraphy of the Tournaisian and the Viséan is mainly based upon foraminifera, rugose corals and conodonts (Conil et al.1991, Poty et al. 2006). It is complemented by the sequence stratigraphy defined by Hance et al. $(2001,2002)$ and elaborated on by Poty et al. (2002), who defined 11 third-order stratigraphic sequences from the uppermost Famennian (Strunian) to the Serpukhovian.

The Upper Devonian and the Lower Tournaisian (Hastarian) lithostratigraphic units observed in the area correspond to formations defined in the Namur-Dinant Basin. These are in stratigraphic order: the middle Frasnian Lustin Limestone Formation, the upper Frasnian Aisemont Fm, the upper Famennian Evieux Fm, the uppermost Famennian (Strunian) Comblain-au-Pont Fm, and the lower Tournaisian (Hastarian) Hastière and Pont d'Arcole Fm (the former locally reworked as breccia blocks in the second).

The uppermost Tournaisian (uppermost Ivorian) to Upper Viséan (Upper Warnantian) lithostratigraphic units are

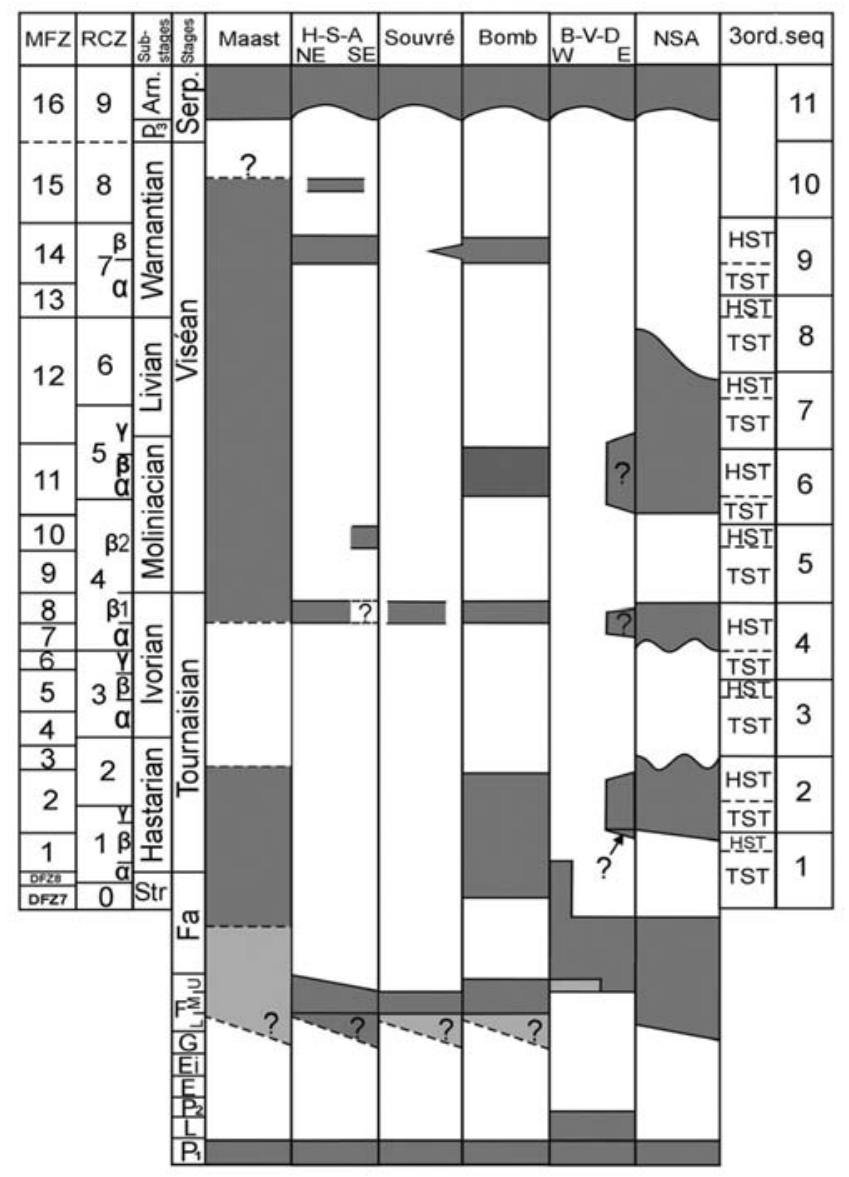

Fig. 2: Biostratigraphy and sequence stratigraphy of the deposits recorded in the Visé-Maastricht sedimentation area and in the eastern part of the Namur sedimentation area. Boxes in light grey indicate deposits which are probably present but were not observed.

MFZ = Mississippian Foraminifer Zones (Devuyst \& Hance, in Poty et al. 2006); RCZ = Rugose Coral Zones (Poty, ibid.); Str = Strunian; P3 = Pendleian; Arn = Arnsbergian; P1 = lower Palaeozoic; $\mathrm{L}=$ Lochkovian, $\mathrm{P} 2$ = Praguian; $\mathrm{E}=$ Emsian; Ei = Eifelian ; $\mathrm{G}$ $=$ Givetian ; F = Frasnian (L: lower; M: middle; U: upper); Fa = Famennian; Serp = Serpukhovian; Maast $=$ Maastricht Graben; H$\mathrm{S}-\mathrm{A}=$ Hermalle-sous-Argenteau block $(\mathrm{NE}=$ north part; $\mathrm{SE}=$ south part); Souvré = Souvré block; Bomb = Bombaye block; B-V-D = Booze-Val-Dieu block ( $\mathrm{W}=$ west part; $\mathrm{E}=$ east part); NSA = east part of the Namur sedimentation area; 3 ord. Seq = third-order sequences (Hance et al. 2001, 2002, Poty et al. 2002); TST = Transgressive Systems Tract (including lowstand system tracts); HST = Highstand Systems Tract (including the falling stage systems tract).

grouped in only two local formations (Poty et al. 2002): the Visé and the Berneau fms. The first consists of pale to grey limestones including four main shallow-water facies: (1) sedimentary limestone breccias with centimetric to pluridecametric boulders of Frasnian age; (2) thick-bedded packstones to rudstones, with sedimentary breccias, forming pluridecimetric to metric fining-upwards sequences, commonly laminated in their upper part; (3) thick-bedded to massive packstones to rudstones; and (4) massive microbial bound- 
stones forming build-ups, rich in macrofossils (mainly brachiopods). The Berneau Fm is composed of thin to thickbedded, dark limestones (mainly packstones and grainstones), with common brachiopods and corals, corresponding to slope and relatively deep-water deposits. It passes laterally to deep-water dark calcareous shales and silicified shales and limestones.

These are overlain by the Namurian Souvré Fm, composed of thin-bedded, grey to black silicified, laminated shales and limestones and/or by shales of the Chokier Fm.

\section{Eustatic variations}

The third-order stratigraphic sequences recognised in Belgium and northern France from the uppermost Famennian (Strunian) to the Lower Namurian, and later extended to England, Poland and South China, correspond to major eustatic variations briefly defined by Poty \& Hance (2008). They have possibly 2-4 Ma durations, but one of them (eustatic sequence 8 overlapping the Middle-Upper Viséan boundary) is possibly less than $1 \mathrm{Ma}$ long. Consideration of the subsidence and sedimentation rates and of the relative sea levels recorded in the deposits, suggests an average amplitude of the eustatic variations of some dozens of meters; however some eustatic changes were larger than the others:

- The upper Ivorian (uppermost Tournaisian) eustatic sequence 4 is characterised by a very high highstand (HST) and the flooding of previously emergent lowlands ("Avins event" of Poty 2007). That very high eustatic rise was responsible for good connections between marine basins and the widespread distribution of taxa of foraminifers, brachiopods and corals. It was followed by a very strong eustatic fall corresponding to the falling stage systems tract (FSST) of sequence 4. That fall was so significant that the transgressive systems tract (TST) and the HST of the following lower Moliniacian (lowermost Viséan) sequence 5 never reached the shallow marine platforms previously covered by the late Tournaisian sea (Hance et al. 2001). Therefore, sequence 5 is recorded only in the deeper parts of the basins, such as the Dinant sedimentation area (DSA) in the Namur-Dinant Basin where lagoonal deposits developed. That suggests a fall of more than $100 \mathrm{~m}$. Shallow platforms were progressively flooded during the TST and the HST of the following sequence 6 (upper Lower Viséan).

- The second highest fall of the sea level occurred at the end of the Viséan and caused, for the second time, the emergence of the carbonate platforms. The latter were affected by intense karstification due to the replacement of the relatively dry Viséan climate by the Namurian wet climate, as shown by the shift from the Viséan carbonatedominant sedimentation to the Namurian siliciclasticdominant one. That is considered as corresponding to a strong growth of the ice caps and the starting of the Upper Carboniferous glaciations (Mii et al. 1999).

\section{Description of the south VSA tectonic units and their deposits}

The tectonic units and their deposits have been described and discussed in Poty (1991). These points are summarised and some details emended here.

\subsection{Booze-Val-Dieu block (Figs. 1, 2)}

This tectonic unit was defined from the work of Ancion et al. (1943), who recognised that the Namurian rested disconformably upon the Famennian and was considered to be the eastern extension of the Brabant Massif (Ancion et al. 1943, Michot 1986).

The Dinantian was considered as being missing and the uppermost Famennian (Strunian) limestones recognised in the Chertal borehole (121E-15) were considered as the youngest deposits below the Namurian (Kimpe et al. 1978). However, a new investigation has yielded the coral Conilophyllum priscum below the contact with the Namurian, a guide species of the RC1 coral Zone indicating that the upper part of the limestone interval can be correlated with the Hastière Formation and with the limestone pebbles included in the conglomerate of La Folie quarry (Bombaye block). Hastarian, Moliniacian and Livian (?) deposits were recognised (Graulich 1984) in a part of the Boland borehole $(122 \mathrm{~W}-260)$ and interpreted as the south border of the Booze-Val-Dieu block, sometimes flooded by the sea from the Namur-Dinant Basin (Bless et al. 1980, Poty 1991).

The block was almost static from the end of the Famennian until the Namurian, and formed a high separating the VSA from the NSA from the Upper Tournaisian onward.

\subsection{Souvré block (Figs. 1-3)}

The Souvré block did not subside and formed a high probably during almost all the Dinantian. The only Tournaisian and Viséan deposits recorded on the block are:

- Uppermost Ivorian deposits in caves developed in the middle Frasnian Lustin limestone Formation (Fig. 3);

- Upper Viséan limestones described by Horion \& Gosselet (1892), but not seen since.

The cave deposits consist of laminated limestone microbreccia grading into fine argillaceous limestone and are dated as uppermost Ivorian (formerly "V1a") by conodonts (Poty 1980). In some cases they display geopetal structures (Fig. 3: B), indicating that the block tilted $45^{\circ}$ to the south after the Frasnian, but remained, at least partly, well above sea level (Poty 1991) and was not flooded before the highest eustatic rise at the end of the Tournaisian. The upper Viséan limestones probably covered lower parts of the tilted block. Frasnian (and upper Viséan) is covered unconformably by Namurian silicified limestones and shales of the Souvré Fm or shales of the Chokier Fm, depending of the local shape of the palaeorelief during the Namurian transgression. 


\subsection{Hermalle-sous-Argenteau block (Figs. 1, 2, 4)}

The eastern part of the block is well exposed in the disused quarries and outcrops situated on the east side of the Meuse Valley, from Argenteau to Visé (Fig. 4), and numerous papers were devoted to these (see references in Poty 1982). Subsurface data of this block are from boreholes: the Hermalle-sous Argenteau borehole (122W-258; Graulich 1975), the Villers-Saint-Siméon borehole (121W-220; Legrand 1977) and the Visé boreholes (122W-291/292; Goemaere \& Vandenven 1989, Poty 1991).

Uppermost Ivorian limestones (MFZ8, RC4 $\beta 1$ ) are the oldest Carboniferous deposits known on the block. They rest directly upon Frasnian rocks. A lower Moliniacian limestone unit (MFZ10, RC432) is present at the southeast corner of the block, in the Argenteau castle rock section; it contains karstic cavities filled with Namurian siliciclastics. Both uppermost Ivorian and lower Moliniacian limestones are overlain by lower Warnantian limestones (MFZ14, RC7ß), comprising a sedimentary megabreccia, proximal turbidites and a microbial build-up (Muchez \& Peeters 1987, Aretz \& Chevalier 2007). The sedimentary breccia is well exposed in the disused quarry "K" (Pirlet 1967b, Poty 1982) and contains cyclopean blocks of Frasnian limestone (up to some dozens of cubic metres). The top of the build-up situated in the disused quarry "F", south of Visé (Fig. 4), is karstified and is laterally covered by a wedge-shaped unit of limestone dated

Fig. 3: Views of palaeokarstic cavities developed in the middle Frasnien Lustin limestone at Souvré (Souvré block).

(A) A large cavity was filled up with laminated limestones (uppermost Ivorian) forming a dome-like structure resulting of the morphology of the footwall. (B) A cavity filled up with calcite except in the small side pipe near the hammer where a thin layer of uppermost Tournaisian sediment defines a geopetal structure. That indicates that the block has tilted of about $45^{\circ}$ before the cavity was filled.
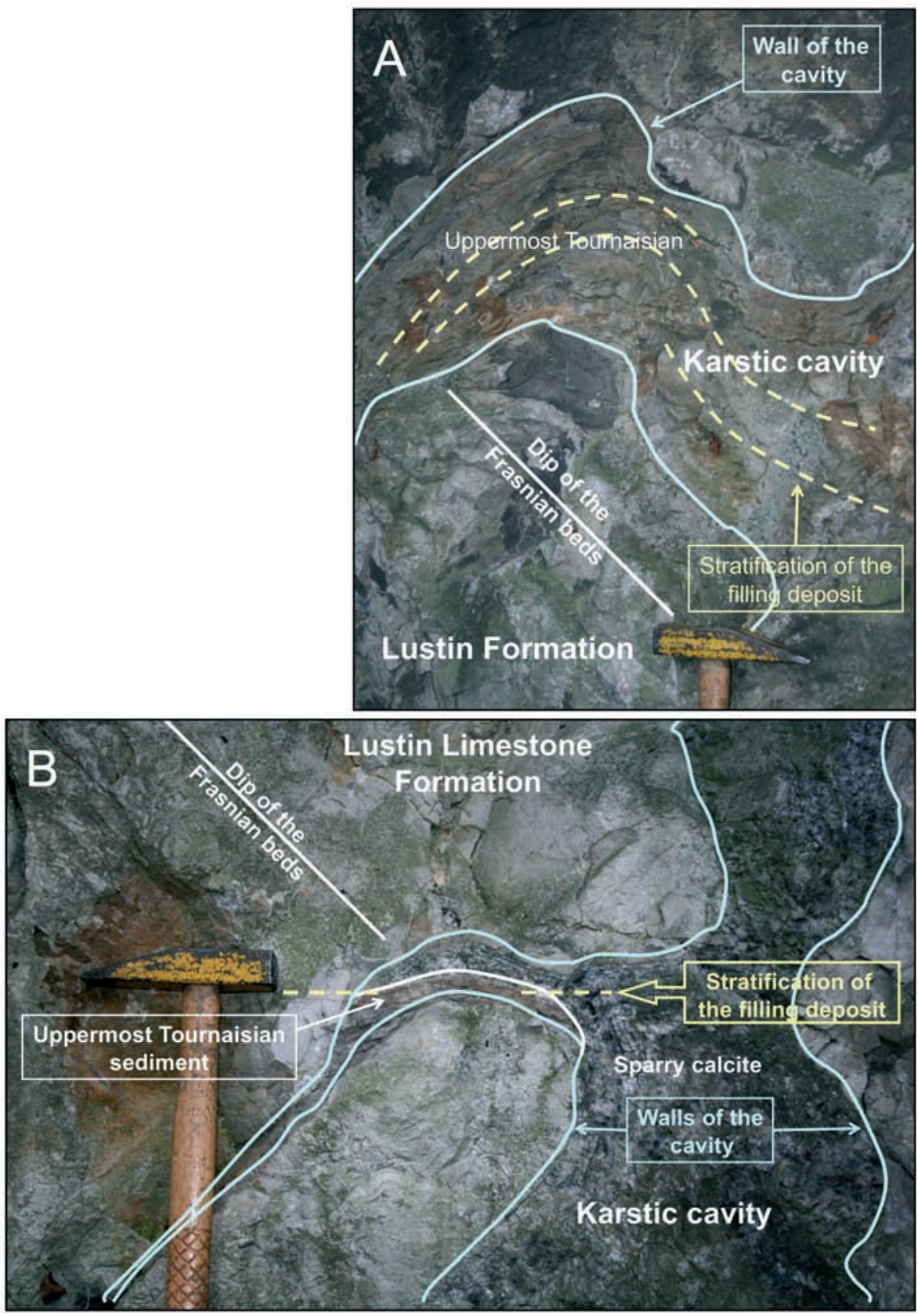


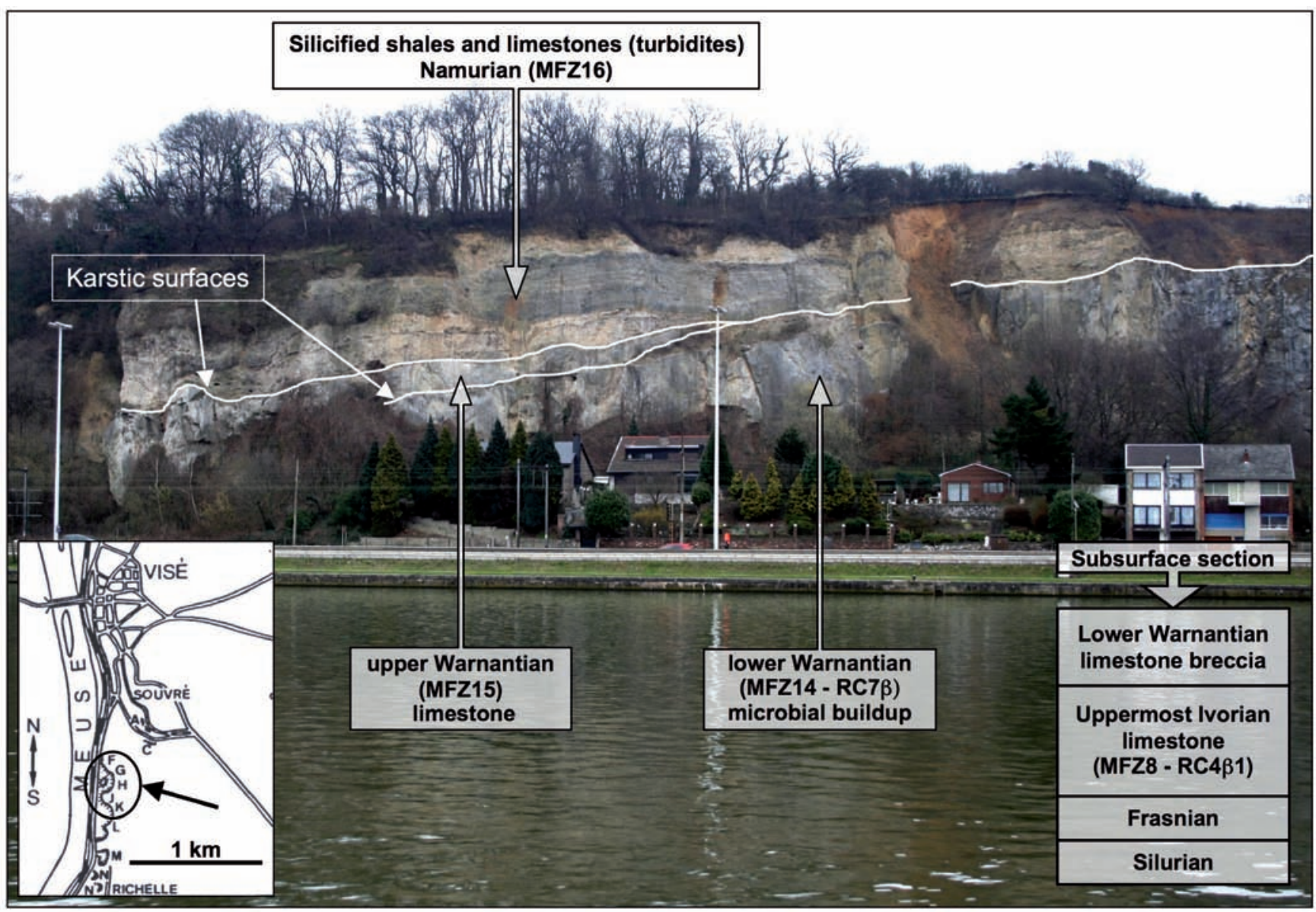

Fig. 4: View of the face of the disused quarry "F", south of Visé along the Meuse River (NE of Hermalle-sous-Argenteau block). The upper Warnantian and the Namurian strata form two bevels, each of them overlying a palaeokarstic surface. The column on the right (no thickness scale) shows the units below the rocks exposed here, which are known from the southern extension of the quarry and the boreholes $122 \mathrm{~W}$ 291/292.

late Warnantian by Pirlet (1967b). The top of that unit was also karstified during the eustatic fall at the Viséan-Namurian boundary. Both early and late Warnantian limestones are overlain by silicified limestones and shales of the Souvré Fm (Namurian); the contact is a low-angle unconformity. In the Argenteau castle rock section, the karstification at the Viséan-Namurian boundary affected the Viséan limestone as deep as the lower Moliniacian, more than $60 \mathrm{~m}$ below the top of the limestone, giving rise to caves filled up by Namurian sandstones.

By correlation, the three first Carboniferous limestone units recorded here correspond respectively to the highstands of the sequences 4, 5 and 9 , and the last to the sequence 10 (highstand?).

\subsection{Bombaye block (Figs. 1, 2)}

Only the west border of that tectonic unit is known from outcrops and disused quarries situated in the Berwinne Valley.

In the La Folie disused quarry, shales and limestones of the Aisemont Fm (upper Frasnian) are overlain by a con- glomerate with pebbles of limestone and a shaly matrix corresponding to a debris flow (Pirlet 1967a). The limestone pebbles have yielded lower Tournaisian foraminifers (Conil, in Kimpe et al. 1978) and $\mathrm{RC} 1 \alpha$ and $\beta$ rugose corals, and can be correlated with the Hastière Fm (lower Hastarian). The matrix has yielded $\mathrm{RCl} \gamma$ corals, ostracods (Bless, pers. Comm.) and brachiopods (Demanet in Charles 1946), similar to those found in the Hastarian Pont d'Arcole Fm. Note that some limestone beds overlying the conglomerate were observed formerly and dated by Conil (in Kimpe et al. 1978) as "middle Tournaisian", the same age as the upper Hastarian Landelies Fm. The Hastarian is overlain unconformably by limestones which are weakly brecciated and contain numerous MFZ8 foraminifers and RC4 $\beta 1$ corals; these are overlain in turn by MFZ11 $-\operatorname{RC} 5(\alpha, \beta)$ limestones. The blocks in the breccia are fragments of Frasnian limestone and dolomite, Famennian siltstone and sandstone, and Hastarian limestone. The Famennian blocks probably originated from the BoozeVal-Dieu block that formed a high at that time.

From nearby outcrops the rest of the Viséan is composed of MFZ14 - RC7 $\beta$ microbial build-ups (Aretz \& Chevalier 2007) and bioclastic limestones. These units correspond respectively 
to the maximum HST of sequence 4 at the top of the Hastarian, the HST of sequence 6 and the HST of sequence 9.

\subsection{Maastricht block system (Maastricht Graben; Figs. 1, 2)}

That tectonic unit is mainly known from boreholes: Heugem1/1a and Kastanjelaan-2 (Bless et al. 1981), Gravensvoeren 108W-359 (Muchez 1988, Laenen 2003), Houtain-SaintSiméon107E-246 (Bouckaert \& Graulich 1966), Lixhe Distrigaz 1997-A, B, C and D (Poty \& Lietart, unpubl. data). Moreover, the Berneau railway cutting, $1 \mathrm{~km}$ northeast of Visé (Pirlet 1968, Kimpe et al. 1978, Poty 1982, 1991), exposes a long section in the Viséan of the upper part of the slope of the graben.

These sections provide the following composite section of the Dinantian:

- More than $100 \mathrm{~m}$ of Hastarian limestone, argillaceous limestone and shale overlying uppermost Famennian (Strunian);

- Up to 400 m of limestone of the MFZ11 - RC5 zones (upper Moliniacian);

- About $100 \mathrm{~m}$ of limestone of the MFZ12 - RC6 zones (Livian);

- About $300 \mathrm{~m}$ of limestone of the MFZ13, 14 - RC7 zones (lower Warnantian);

- More than $100 \mathrm{~m}$ of silicified limestone and shales of the Souvré Fm (upper Warnantian, Namurian).

The Ivorian was not recognised and is probably a stratigraphical gap, as in the NSA and in the KSA, except for its top (HST of sequence 4), which is probably present but not yet recognised, being known in the Hermalle-sous-Argenteau, Souvré and Bombaye blocks.

From the upper Moliniacian (MFZ11-RC5), the deposits comprise debris flows, turbidites and basinal argillaceous limestones that are sometimes silicified, indicating that the Maastricht Graben became more active. Blocks in debris flows and turbidites are Frasnian limestone and dolomite and Dinantian limestone reworked from the slope.

\section{Eustatic and block-faulting tectonic evolution of the southern part of the VSA (Figs. 5, 6)}

From its formation around the Givetian-Frasnian boundary, the VSA evolved as a part of the NSA, with the deposit of the middle Frasnian Lustin Fm, the upper Frasnian Aisemont and Lambermont fms, the latter being only recorded in the Bolland borehole (Graulich 1984).

During the Famennian, the sea level was relatively low and sedimentation developed in the east part of the NSA, on the Booze-Val-Dieu unit and in the Maastricht block system. Famennian rocks are not known on the Hermalle-sous-Argenteau, Souvré and Bombaye blocks, which were emergent resulting in the karstification of the Lustin Limestone Fm (Poty 1982). During the Hastarian (Fig. 5A), the rise of sea level, corresponding to the end of sequence 1 and to sequence 2 , is marked by a marine sedimentation in the area, except on the Hermalle-sous-Argenteau and Souvré blocks, which remained emergent. These sediments are similar to those deposited in the Namur-Dinant Basin showing that
Fig. 5: Evolution of the studied area during the Tournaisian with regard to the eustatic variations and the block-faulting tectonics. (A) During the early Tournaisian (Hastarian), tectonic movements affected the Bombaye and probably the Booze-Val-Dieu blocks and destabilised the Hastarian deposits, giving rise to debris flows (grey arrows). (B) During the late Tournaisian (Ivorian), the Namur sedimentation area and the Visé-Maastricht sedimentation area were emerged and recorded any marine deposit. (C) The high eustatic level, reached at the end of the Tournaisian (sequence 4, top of Ivorian), flooded the areas, except the Booze-Val-Dieu and the Souvré areas which were eroded and gave debris onto the Bombaye block. The karstic cavities, previously developed into the middle Frasnian Lustin limestone, were filled up at that time by marine deposits $1=$ BoozeVal-Dieu block; 2 = Souvré block; $3=$ Hermalle-sous-Argenteau block; $4=$ Bombaye block.

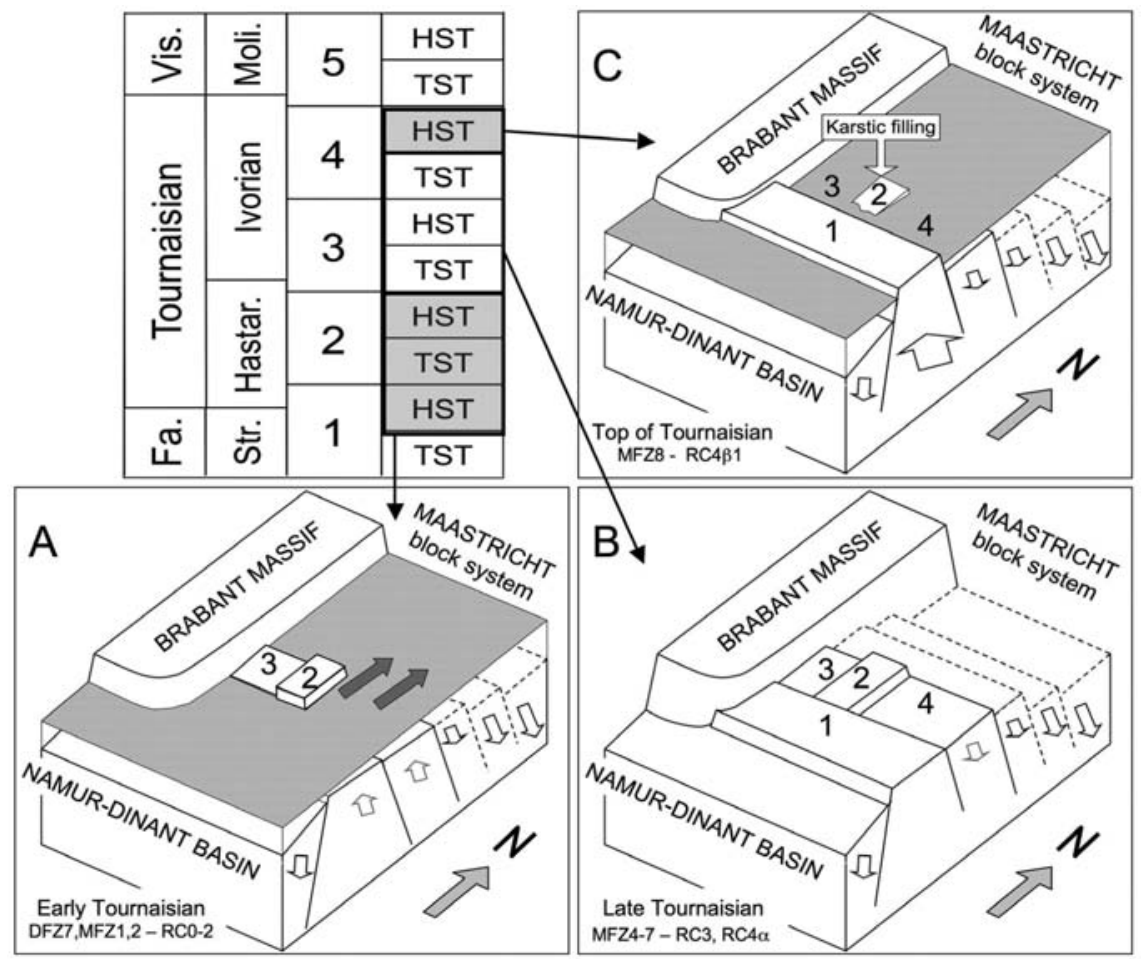




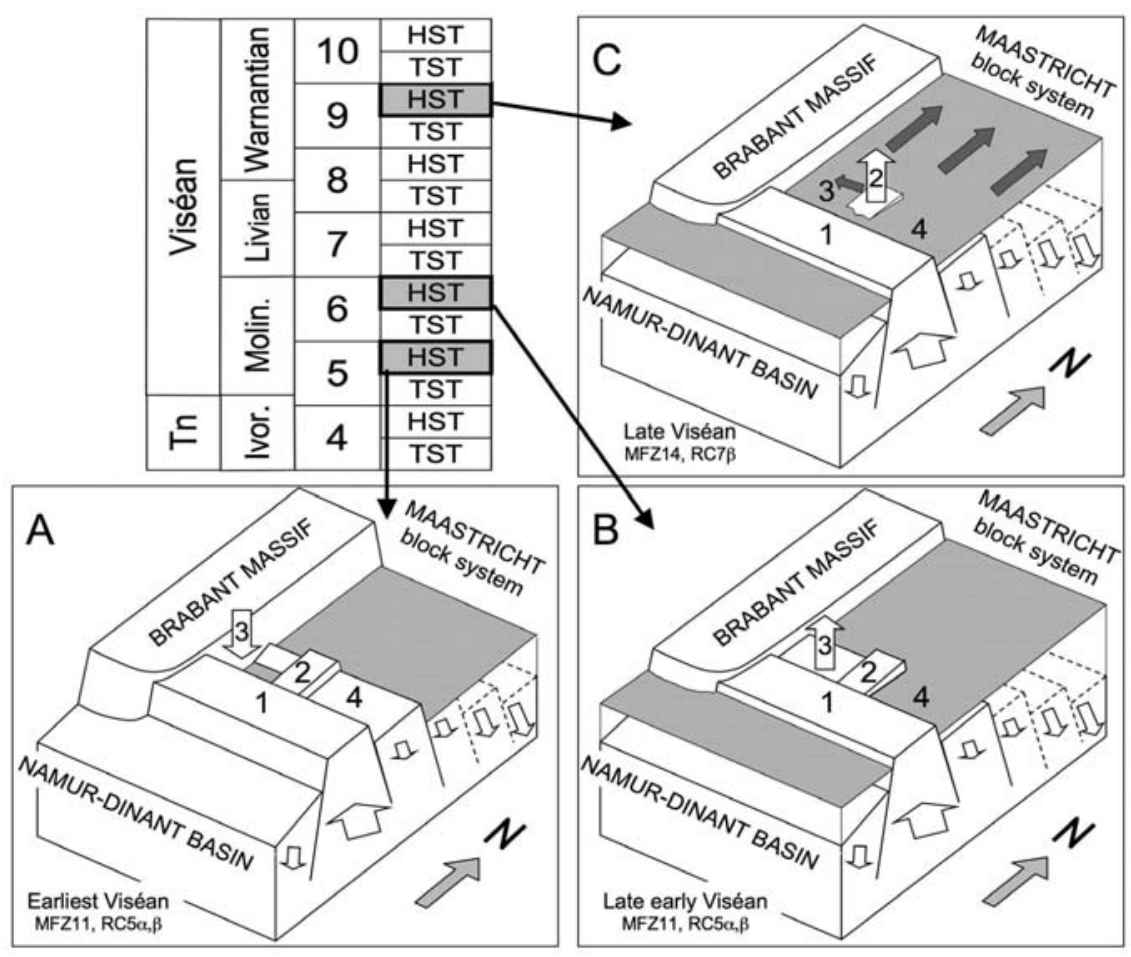

Fig. 6: Evolution of the studied area during the Viséan with regard to the eustatic variations and the block-faulting tectonics.

(A) During the earliest Viséan (early Moliniacian) eustatic sequence 5, only the south part of the Hermalle-sous-Argenteau block was flooded by the sea because of a downward tectonic movement. The Maastricht block system was also probably flooded at the same time. (B) The high eustatic level, reached during the highstand of the sequence 6 (late early Viséan, late Moliniacian), flooded the Namur sedimentation area, the Maastricht block system and the Bombaye block, but not the Souvré block which remained elevated, and the Hermallesous-Argenteau block which probably uprised at that time. (C) During the highstand of the early Warnantian sequence 9 (early late Viséan), the Hermalle-sous-Argenteau and the Bombaye blocks were subsident and the former recorded Frasnian debris coming from the fault cliff separating it from the Souvré block. An input of Frasnian debris affected also the deposits of the slope to the Maastricht Graben. The eastern part of the Namur sedimentation area was also covered by Warnantian deposits, but these were eroded and disappeared during the Viséan-Namurian transition.

1 = Booze-Val-Dieu block; 2 = Souvré block; 3 = Hermalle-sous-Argenteau block; 4 = Bombaye block.

there was still good connections with the latter. Tectonic activity locally destabilised the deposits and gave rise to debris flows on the Bombaye block.

During the Ivorian (Fig. 5B), sea level remained relatively low, and only the maximum of the eustatic rise, corresponding to the end of the highstand of the sequence 4, flooded the area (Fig. 5C), with the exception of the BoozeVal-Dieu block, which was uplifted, as shown by the development of sedimentary breccia including Famennian debris coming from the block. It is from that time onward that the VSA lost its connection with the Namur-Dinant Basin and became more closely related to the northern Campine Basin. The karstic cavities, developed previously in the Souvré block, were flooded and filled up with sediments (Fig. 3).

Afterwards, during the early Moliniacian (Fig. 6A), the sea level fell dramatically (sequence 5) and all the shallow platforms became emergent. In the Namur-Dinant Basin, only the Dinant sedimentation area recorded lowermost Viséan deposits, the rest of the basin being emergent. In the VSA, deposits corresponding to the highstand of sequence 5 developed locally on the Hermalle-sous-Argenteau block, indicating a downward movement of the block. Deposits of sequence 5 were not observed in the Maastricht unit, but are probably present.

At the end of the Moliniacian (Fig. 6B), the eustatic rise corresponding to sequence 6 caused the flooding of the Maastricht block system and the Bombaye block, but did not reach the Hermalle-sous-Argenteau and Souvré blocks which did not subside and may have been uplifted. The Booze-Val-Dieu was always a high and was to remain in that position until the Namurian.

The Livian sequence 7 is well developed in the NSA, but is only present in the Maastricht block system. The eustatic rise was possibly not high enough to flood the other blocks.

The short-lived sequence 8 , which involved only a small sea level rise, was not recognised in the VSA, but it possibly led to some deposition in the Maastricht block system.

During the early Warnantian (Fig. 6C), the Hermallesous-Argenteau and the Bombaye blocks subsided. Periodical reactivation of the fault separating the Hermalle-sousArgenteau block from the Souvré block gave rise to a cliff which gave rise to an input of debris sometimes cyclopean 
and to a sedimentary breccia at the foot of the cliff (disused quarry "K"). Sedimentary breccias with Frasnian debris from the Souvré block developed also north of the latter, in the slope of the Maastricht Graben (Berneau railway cutting section). The TST of sequence 9 is well developed in the Maastricht Graben, but is poorly recorded in the Hermallesous-Argenteau and Bombaye blocks where almost all the lower Warnantian corresponds to the HST (MFZ14, RC7 $\beta$ ). Microbial build-ups developed in these two blocks, one of them being well exposed in the wall of the disused quarry ("F") situated just south of Visé (Fig. 4). The karstification of the top of that build-up is probably linked to its emersion during the eustatic fall between sequences 9 and 10. The bevel of upper Warnantian limestone on the flank of the build-up corresponds to its flooding by sequence 10 .

The Souvré and the Booze-Val-Dieu blocks remained emergent during all the Warnantian.

Because of the drastic sea-level fall at the end of the Viséan, the Hermalle-sous-Argenteau and Bombaye blocks were emergent and the Viséan limestone was more or less karstified. In the Argenteau castle rock section, the karstification affected at least $60 \mathrm{~m}$ of Viséan limestone (it reached the lower Moliniacian limestone), whereas $2 \mathrm{~km}$ northward, in the quarry "F", only the top of the limestone is karstified (Fig. 4). That indicates that the block was tilted northward at that time with its south part more elevated above the sea level than its north part.

All the blocks of the area were flooded during the Namurian sea level rise, because at that time all the north of the Namur-Dinant Basin and the VSA evolved to a foreland basin due to the Variscan orogeny.

\section{Conclusion}

During the Hastarian, the Hermalle-sous-Argenteau and the Souvré blocks were emergent, while the Booze-Val-Dieu and the Bombaye blocks were the site of some deposition. Occurrence of breccia on the latter suggests that tectonic movements destabilised these deposits.

The other Dinantian deposits recorded in the south part of the Visé-Maastricht sedimentation area, on the Hermallesous-Argenteau and Bombaye blocks, can be correlated with HST of the uppermost Tournaisian and Viséan third-order sequences, indicating that these blocks remained largely emergent and were flooded only during very high eustatic rises. The local record of lower Moliniacian limestone in the Hermalle-sous-Argenteau block, suggests that the block was subsiding at that time, while the others did not. The Souvré block remained emergent and was karstified, at least from the Famennian onward. Its karstic cavities were filled with marine deposits during the last Ivorian eustatic rise (sequence 4) that corresponds to the highest rise recognised in the Dinantian.

The Maastricht block system subsided during the late Devonian and the Tournaisian, but it was sometimes emergent during periods of low sea level. From the Moliniacian onward, it evolved to a graben recording deep-water deposits.
During the early Warnantian, the fault separating the Hermalle-sous-Argenteau and the Souvré blocks was reactivated and gave rise to a fault cliff from which erosion gave an input of Frasnian blocks into the Warnantian deposits of the Hermalle-sous-Argenteau block and in the slope of the Maastricht graben.

Therefore, the succession of deposits and the numerous gaps in the southern part of the VSA were mainly related to third-order eustatic variations, and only secondarily by the block faulting tectonic activity that remained relatively minor.

\section{Acknowledgements}

We wish to thank George Sevastopulo and Markus Aretz who reviewed the manuscript for their helpful comments, suggestions and corrections.

\section{References}

Ancion, C., Van Leckwyck, W. \& Ubaghs, G. (1943): A propos de la bordure méridionale du synclinal de Liège, à l'aval de Liège: la ride famennienne de Booze - Le Val-Dieu, à la limite septentrionale du plateau de Herve. - Ann. Soc. géol. Bélgique, LXVI: M299-M335, Liège (Vaillant-Carmanne).

Aretz, M. \& Chevalier, E. (2007): After the collapse of stromatoporid-coral reefs - the Famennian and Dinantian reefs of Belgium: much more than Waulsortian mounds. - In: Alvaro, J.J., Aretz, M., Boulvain, F., Munnecke, A., Vachard, D. \& Vennin, E. (eds.): Palaeozoic reefs and bioaccumulations: climatic and evolutionary controls. - Geol. Soc. London, Spec. Publ., 275: 163-188, London (Geol. Soc. London).

Bless, M.J.M., Conil, R., Defourny, P., Groessens, E., Hance, L. \& Hennebert, M. (1980): Stratigraphy and thickness variations of some Strunio-Dinantian deposits around the Brabant Massif. Meded. Rijks Geol. Dienst, 32 (8): 56-65, Haarlem (Rijks Geol. Dienst).

Bless, M.J.M., Boonen, P., Bouckaert, J., Brauckmann, C., Conil, R., Dusar, M., Felder, P.J., Felder, W.M., Gokdag, H., Kockel, F., Laloux, M., Langguth, H.R., Van Der Meer Mohr, C.G., Meessen, J.P.M.T., Op Het Veld, F., Paproth, E., Pietzner, H., Plum, J., Poty, E., Scherp, A., Schulz, R., Streel, M., Thorez, J., Van Rooijen, P., Vanguestaine, M., Vieslet, J.L., Wiersma, D.J., Winkler Prins, C.F. \& Wolf, M. (1981): Preliminary report on Lower Tertiary-Upper Cretaceous and Dinantian-Famennian rocks in the boreholes Heugem-1/1a and Kastanjelaan-2 (Maastricht, The Netherland). - Meded. Rijks Geol. Dienst, 35 (15): 333-415, Haarlem (Rijks Geol. Dienst).

Bouckaert, J. \& Graulich, J.M. (1966): Sondage de Houtain-SaintSiméon. - Serv. géol. Belgique, Prof. Pap., 1966 (2): 1-5, Bruxelles (Serv. géol. Belgique).

Charles, F.L. (1946): Observations sur le massif de Visé. - Bull. Soc. Belge Géol. Paléontol. Hydrol., LV: 50-53, Bruxelles (Soc. Belge Géol. Paléont. Hydrol.).

Conil, R., Groessens, E., Laloux, M., Poty, E. \& Tourneur, F. (1991): Carboniferous guide foraminifers, corals and conodonts in the Franco-Belgian and Campine Basins. - Courier Forsch.-Inst. Senckenberg, 130: 15-30, Frankfurt a. M. (Senckenbergische naturforsch. Ges.). 
Goemaere, E. \& Vandenven, G. (1989): The Visé boreholes. - Int. meeting Caledonides Midlands Brabant Massif, Abstract: 27.

Graulich, J.-M. (1975): Le sondage de Hermalle-sous-Argenteau. - Serv. géol. Belgique, Prof. Pap., 1975 (4): 1-12, Bruxelles (Serv. géol. Belgique).

Graulich, J.-M. (1984): Coupe géologique passant par les sondages d'Hermalle-sous-Argenteau, Bolland, Soumagne, Soiron, Pepinster 2 et 1 et Juslenville - commentaires. - Bull. Soc. Belge Géol., 93 (1-2): 45-49, Bruxelles (Soc. Belge Géol.).

Hance, L., Poty, E. \& Devuyst, F.-X. (2001): Stratigraphie séquentielle du Dinantien type (Belgique) et corrélation avec le Nord de la France (Boulonnais, Avesnois). - Bull. Soc. géol. France, 172 (4): 411-426, Paris (Soc. géol. France).

Hance, L., Devuyst, F.-X. \& Poty, E. (2002): Sequence stratigraphy of the Belgian Lower Carboniferous - tentative correlation with the British Isles. - In: Hills, L.V., Henderson, C.M. \& Bamber, E.W. (eds.): Carboniferous and Permian of the world. - Canadian Soc. Petroleum Geol., Mem., 19: 41-51, Calgary (Canadian Soc. Petroleum Geol.).

Horion, C. \& Gosselet, J. (1892): Etude stratigraphique sur les calcaires de Visé. - Ann. Soc. géol. Nord, 20: 194-212, Lille (Soc. géol. Nord).

Kimpe, W.F.M., Bless, M.J.M., Bouckaert, J., Conil, R., Groessens, E., Meessen, J.P.M.T., Poty, E., Streel, M., Thorez, J. \& Vanguestaine, M. (1978): Paleozoic deposits east of the Brabant massif in Belgium and Netherlands. - Meded. Rijks Geol. Dienst (The Netherlands), 30 (2): 37-103, Haarlem (Rijks Geol. Dienst).

Laenen, B. (2003): Lithostratigrafie van het pre-Tertiair in Vlaanderen. Deel II: Dinantiaan \& Devoon. - Vito: 86 p.

Legrand, R. (1977): Précision sur le rejet de la Faille bordière. Le sondage E4bis à Villers-Saint-Siméon. - Serv. géol. Belgique, Prof. Pap., 1977 (9): 1-22, Bruxelles (Serv. géol. Belgique).

Michot, P. (1986): De la faille des Aguesses-Asse, par le sondage de Porcheresse, à l'invalidation du concept de Synclinorium de Verviers. - Bull. Soc. Belge Géol., 95 (1): 9-25, Bruxelles (Soc. Belge Géol.).

Mii, H.-S., Grossman, E.L. \& Yancey, T.E. (1999): Carboniferous isotope stratigraphies of North America: implications for Carboniferous paleoceanography and Mississippian glaciation. Geol. Soc. America, Bull., 111: 960-973, Boulder (Geol. Soc. America).

Muchez, P. (1988): Sedimentologische, diagenetische en geochemische studie van de dinantiaan strata ten noorden van het Brabant massif (Bekken van het Kempen). - PhD thesis: 311 p., Leuven (Katholieke Univ. Leuven).

Muchez, P. \& Peeters, C. (1987): The occurrence of a cryptalgal reef structure in the upper Viséan of the Visé area (the Richelle quarries). - Ann. Soc. géol. Bélgique, 109: 573-577, Liège (Vaillant-Carmanne).

Pirlet, H. (1967a): Mouvements épeirogéniques dévono-carbonifères dans la région de Visé; la carrière de "La Folie" à Bombaye ( $1^{\text {ère }}$ note sur les calcaires de Visé). - Ann. Soc. géol. Bélgique, 90 (2): B103-B117, Liège (Vaillant-Carmanne).

Pirlet, H. (1967b): Nouvelles interprétations des carrières de Richelle: le Viséen de Visé (2e note sur les calcaires de Visé). Ann. Soc. géol. Bélgique, 90 (4): B299-B328, Liège (VaillantCarmanne).

Pirlet, H. (1968): La tranchée de Berneau à Visé et la sédimentation dévono-carbonifère dans la région de Visé ( $3^{\mathrm{e}}$ note sur les calcaires de Visé). - Ann. Soc. géol. Bélgique, 90 (9): B751-765, Liège (Vaillant-Carmanne).

Poty, E. (1980): Evolution and drowning of paleokarst in Frasnian carbonates at Visé, Belgium. - Meded. Rijks Geol. Dienst, 32 (7): 53-55, Haarlem (Rijks Geol. Dienst).

Poty, E. (1982): Paleokarsts et brèches d'effondrement dans le Frasnien moyen des environs de Visé. Leur influence dans la paléogéographie dinantienne. - Ann. Soc. géol. Bélgique, 105: 315337, Liège (Vaillant-Carmanne).

Poty, E. (1991): Tectonique de blocs dans le prolongement oriental du Massif du Brabant. - Ann. Soc. géol. Bélgique, 114 (1): 265-275, Liège (Vaillant-Carmanne).

Poty, E. (1997): Devonian and Carboniferous tectonics in the eastern and southeastern parts of the Brabant Massif (Belgium) Aardkundige Meded., 8: 143, 144, Leuven (Univ. Pr.).

Poty, E. (2007): The Avins event: a remarkable worldwide spread of corals at the end of the Tournaisian (Lower Carboniferous). In: Hubmann, B. \& Piller, W.E. (eds.): Fossil corals and sponges. - Proceedings of the 9th Int. Symp. on Fossil Cnidaria and Porifera, Graz 2003. - Schriftenr. erdwiss. Komm. (Oesterreichische Akad. Wiss.), 17: 231-249, Wien (Springer).

Poty, E. \& Hance, L. (2008): Global sea level and climatic changes during the Lower Carboniferous. - In: Kröger, B. \& Servais, T. (eds.): Abstr. Int. Congr. Palaeozoic Climates, Lille, France: 80.

Poty, E., Aretz, M. \& Barchy, L. (2002): Stratigraphie et sédimentologie des "Calcaires à Productus" du Carbonifère inférieur de la Montagne Noire (Massif Central, France). - C. R. Geosci., 334: 843-848, Paris (Elsevier).

Poty, E., Devuyst, F.-X. \& Hance, L. (2006): Upper Devonian and Mississippian foraminiferal and rugose coral zonation of Belgium and Northern France: a tool for Eurasian correlations. - Geol. Mag., 143: 829-857, Cambridge (Cambridge Univ. Pr.).

Manuscript received: 20.02.2010

Accepted for publication: 13.02.2011 